\title{
Present soils and past land use: the "bracken economy" in Lea-Artibai County (Basque Country, northern Spain) in the late nineteenth and early twentieth centuries
}

\author{
José Ramón Olarieta, Gerardo Besga \& Ana Aizpurua
}

KEYWORDS: metabolic rift, soil acidity, soil degradation, soil fertilization.

JEL CODES: N53, Q15, Q24, Q34.

oils in Lea-Artibai County (northern Spain) show three significant features: $\circlearrowleft$ frequent absence of $A$ horizons, higher nutrient concentrations in the surface mineral horizon of past or present arable fields compared to those in forest or shrubland, and the common presence of calcareous horizons in arable fields which is out of character with the region's humid climate. Farmers stopped applying lime around 1950, so the third feature is interpreted as the result of over-liming since the eighteenth century. The "maize revolution" that began in the mid-seventeenth century relied upon a three-crop rotation system using bracken as a primary fertilizer along with animal manure and lime obtained from local kilns that burned gorse. Extraction of these plant materials resulted in a negative phosphorus balance of phosphorus and the acidification of shrubland soils. The county could not accommodate these various land uses in the early twentieth century, and extraction of leaf litter from forests and shrublands became necessary. In the "concentrational agriculture" of the maize revolution, organic matter and nutrients accumulated in arable fields and diverted ecological pressure onto shrubland and forest soils, creating a "metabolic rift" that is still evident in the soils of Lea-Artibai County. 


\title{
Suelos actuales y uso histórico del territorio: la "economía del helecho» en la comarca de Lea-Artibai (País Vasco) entre finales del siglo XIX y principios del xx
}

\author{
PALABRAS CLAVE: brecha metabólica, degradación de suelos, fer- \\ tilización de suelos, suelos ácidos.
}

\section{CÓDIGOS JEL: N53, Q15, Q24, Q34.}

os suelos de la comarca de Lea-Artibai (Bizkaia) muestran tres rasgos signi-
ficativos: frecuente ausencia de horizonte A, mayor concentración de nutrien-
tes en el horizonte mineral superficial de parcelas que en algún momento se han cultivado en comparación con aquellas que se han mantenido siempre en uso forestal o matorral, y la frecuente presencia de horizontes calcáreos en contradicción con el clima lluvioso de la región. Dado que la aplicación de cal desapareció hacia 1950, este último rasgo se interpreta como un resultado del exceso de encalado practicado históricamente. La revolución del maíz iniciada en el siglo XVII se apoyó en el uso del helecho como fertilizante básico, junto con deyecciones de los animales, y la aplicación de cal obtenida en hornos alimentados con argoma. La extracción de estos materiales vegetales implicaba un balance negativo de fósforo y la acidificación de los suelos de matorral. La comarca no podía acomodar estos usos a principios del siglo Xx, y se hizo necesaria la extracción de hojarasca de bosques y matorrales. La revolución del maíz estuvo basada en una agricultura de concentración en la que la materia orgánica y los nutrientes se acumulaban en los campos de cultivo a costa de desviar la presión ecológica hacia los suelos de bosques y matorrales, creando una brecha metabólica que todavía hoy es evidente en los suelos de Lea-Artibai.

Received: 2018-09-03 - Revised: 2019-02-01 - Accepted: 2019-02-21

José Ramón Olarieta [orcid.org/0000-0003-4951-4419] is Lecturer in Soil Science at the Universitat de Lleida. Address: Dept. Medi Ambient i Ciències del Sòl, Universitat de Lleida, c/ Rovira Roure, 191, 25198 Lleida (Spain).E-mail:jramon.olarieta@macs.udl.cat

Gerardo Besga [orcid.org/0000-0002-5557-8788] is Head of the Scientific Area at Neiker. Address: Neiker-Tecnalia, Bizkaia Technological Park, 812, 48160 Derio (Spain).E-mail: gbesga@neiker.eus Ana Aizpurua [orcid.org/0000-0002-4791-4788] is Senior Researcher at the Department of Plant Production and Protection at Neiker. Address: Neiker-Tecnalia, Bizkaia Technological Park, 812, 48160 Derio (Spain).E-mail:aaizpurua@neiker.eus 


\section{SOIL NUTRIENTS IN AGRICULTURAL HISTORY: NOT ONE BUT A DOUBLE METABOLIC RIFT}

Agrarian systems reflect the interaction between specific social systems, land units, and historical periods, and their analysis may be performed at different spatial scales (crop, field, farm, township...) with different criteria required at each scale (Giampietro, Cerretelli \& Pimentel, 1992). Changes in any of the components involve the appearance of a new agroecosystem, whether they are related to the introduction of new crops (González Cembellín, 1990), to the expansion or contraction of human population (Arnáez et al., 2011), to climate changes (Aragón, 2013; Tello et al., 2017), or to changes in the land base of the agroecosystem (Evans, 1990). Agroecosystems are continuously evolving; their temporal scope is generally quite limited, and cannot provide a long-term perspective on successful agricultural management (Altieri, 2004: 41) if by "long-term" we mean centuries. Terms such as "modern" or "traditional systems" therefore provide little information about the system in question.

The literature shows various cases of "traditional" agricultural systems running on a nutrient deficit at the scale of the crop field (González de Molina et al., 2015; Corbacho, 2017), and even producing intense soil erosion (Soto et al., 1995; Lasanta, NadalRomero \& Errea, 2017). The rainfed Leeward Kohala Field System in Hawai'i depleted soil phosphorus between 1650 and 1800 (Ladefoged \& Graves, 2010). Cotton production in the southeastern region of the United States of America (USA) showed a net nitrogen deficit before the Civil War, had a disastrous impact on soils between 1865 and 1950 as a result of soil erosion, and was running on a phosphorus deficit until the adoption of synthetic fertilizers around 1920 (Richter \& Markewitz, 2001: 119-33). Similarly, various agricultural systems around the world may have produced negative phosphorus budgets (Newman, 1997), and English agriculture in the fourteenth century, at least in some areas, showed declining yields as a result of such deficit (Newman \& Harvey, 1997). But a decline in any nutrient, or in organic matter, may not necessarily result in declining yields, because, as Vitousek et al. (2010:36) propose, ecosystems exhibit threshold responses to gradual changes in environmental conditions.

Christiansen (1996) proposed the concept of "concentrational agriculture" to characterize the fluxes of nutrients within wider agricultural ecosystems and defined it as types of agriculture based on local concentration of plant nutrients. But the concept of concentrational agriculture may be widened to include not only nutrients but also water and other resources. Inhabitants of the island of Mangaia (Polynesia) provoked profound and irreversible modifications of the mountain ecosystems in order to produce soil erosion in these 
mountains, and increase the size of the alluvial basins and develop their irrigated agriculture in the lowlands (Kirch, 1994: 309).

In any case, many pre-industrial agroecosystems relied, to a greater or lesser extent, on the import of materials from other land units of the system (i.e., forests, heathland, pastures) as fertilizers and/or amendments for the arable land (Christiansen, 2001; Balboa \& Fernández Prieto, 1996; Tello et al., 2010, 2012; Galán del Castillo, 2017). The "nutrient carriers" were quite diverse, and some of these imported materials were applied directly on the agricultural land, others were used as bedding for the farm animals and then applied to the soil mixed with dung and slurry, while other materials were burnt prior to their application in the field (Olarieta et al., 2011). Over 60,000 carts of peat ashes were imported into Belgium from the Netherlands in 1761 to fertilize agricultural fields (Lindemans, 1952, cited by Langohr, 2001). In some cases, these materials were not intended as nutrient carriers but as amendments to improve the physical characteristics of soils. That was the case with the organic matter included in all these plant materials, but also with the sand extracted from beaches or the peat directly mined from heathland soils that improved the arable land of many regions in northern Europe. The end result of this transfer of materials was the production of "plaggen soils" up to $100 \mathrm{~cm}$-deep in some arable fields of northern Europe in a process that took over 700 years (Davidson, 1982: 17-8). In the home gardens around Paris during the early twentieth century tenants were allowed to remove and take with them the $0.5 \mathrm{~m}$ of topsoil from the plots at the end of their tenancy (Cascón, 1918: 19).

But such concentration of nutrients in arable fields cannot be delinked from the complementary depletion of nutrients, or even wholesale soil-mining, imposed on peatland, pastures, shrublands, and forests. A farm in Denmark c. 1840 transferred over $210 \mathrm{Mg} \cdot \mathrm{y}^{-1}$ of various materials from 270 ha of heathland to its $2-3$ ha of arable land (Christiansen, 2001). Depletion of soil nutrients in the outfields of farms in Greenland in the eleventh-fifteenth centuries is still evident today (Golding et al., 2015).

The significance of such past transfers of materials both for the importing fields and for the source fields is still relevant today. The infield of the farm in Denmark studied by Christiansen (2001) still requires about $50 \mathrm{~kg}$ of fertiliser less per hectare than the surrounding areas 150 years after those transfers of nutrients were conducted. The increased $\mathrm{pH}$ and levels of plant nutrients in agricultural soils of Belgium can be traced back to similar practices (Langohr, 2001). Koerner et al. (1997) show how fields which are now forests in the Vosges mountains in France but were arable land in the nineteenth century have higher $\mathrm{pH}$ values and phosphorus concentrations than fields that have always remained as forests, and how present vegetation is influenced as a result. Similar patterns appear in the USA (Richter \& Markewitz, 2001: 134-47). 
Karl Marx proposed the concept of a "metabolic rift" to express the rupture between humans and nature under industrial capitalism. He described the transfer of soil nutrients from agricultural to urban areas, and eventually into streams, as a result of the social division of labour, leading to the depletion of agricultural soils (Foster, 2000: 15563). Some authors have criticized the concept with inaccurate arguments (e.g., Schneider \& McMichael, 2010). While some nutrients may be replenished in the arable fields from renewable resources (e.g., nitrogen from the atmosphere), phosphorus in particular, cannot be obtained from any renewable resource and is generally absent, or only present in extremely small amounts, in geological materials. From the point of view of an objective concept of sustainability (Hueting \& Reijnders, 1998), any negative nutrient budget implies an unsustainable agroecosystem. At best, a negative budget may be sufficiently small in comparison to the nutrient stock in the soil that soil depletion would take place in such a "long term" (may be millennia?) as to be considered "sustainable".

\section{LEA-ARTIBAI COUNTY AND ITS PRESENT SOILS}

Lea-Artibai County covers 20,584 ha in the province of Bizkaia in the humid area of the Basque Country in northern Spain. The population in the county has steadily increased since the eighteenth century, from 16,176 inhabitants in 1860 , to 19,514 in 1920 , and a maximum of 28,756 in $1970^{1}$.

It is a mountainous county, stretching from sea level up to $1,028 \mathrm{~m}$, and only $14 \%$ of its land, about 2,957 ha, has a slope of less than $20 \%$. It has a temperate humid climate, with a mean annual rainfall of $1,100-1,550 \mathrm{~mm}$, an estimated mean annual drainage of $700 \mathrm{~mm}$, and a mean annual temperature of about $14^{\circ} \mathrm{C}$.

Soil surveys of the county include data on 339 soil profiles (Olarieta, 1993; Olarieta et al., 2006) covering all the soil parent materials and land uses present in the county. We confirmed the past land use of these soils (i.e., arable, grassland, forestry, or shrubland) as described by the farmers using the earliest available aerial photographs of the region, which date to 1946 .

Although no erosion processes were obvious at the time of the surveys, soil profile features showing past erosion were common, with $16 \%$ of the 339 soils sampled showing an A horizon less than $20 \mathrm{~cm}$ deep and another $2 \%$ showing no A horizon at all. Within the

1. Estimated from Enríquez (1996), Galarza (2000), López Musatadi (1998), Lorenzo (1996), Martínez Fernández (1993), Olabarría (1997), and Prado (2004). 
sampled soils, those kept under arable always had slopes of less than $23 \%$, but in the past a significant amount of land had been under a clear risk of water erosion, as $6 \%$ of those sampled soils that were under arable in 1946 had slopes over $40 \%$, and $17 \%$ had slopes of $20-40 \%$.

Soil erosion producing such features may have happened in any historical period, but must have been frequent in the nineteenth and early twentieth century. Humboldt (1999: 95), who travelled around the region in 1799, described how fields and home gardens climb the steepest hills due to the assiduity of the inhabitants, and Zamacola (1900:5) praised the industriousness of the farmers, such that even the top of the mountains and the deepest gullies were cultivated in many places. Even accounting for literary hyperbole, soil erosion by rainfall must have been intense in these circumstances. In the 1950s as most fields of maize [in the township of Aulestia] are on slopes, the soil tends to be washed down. Therefore, the farmer loads a basket or a cart with this soil and takes it back to the upper part of the field. Needless to say this is a hard and time-consuming job (Douglass, 1977, vol. 1: 53).

We compared by means of the Kruskal-Wallis test the soil characteristics (Table 1) of two different kinds of fields which currently support forest (Pinus radiata D. Don) plantations or shrubland: "former arable" fields were under arable in 1946 (number of samples $\mathrm{n}=34$ ) while "continuous forest" fields were shrubland or forest at that time $(\mathrm{n}=$ 129). Continuous forest fields generally exported plant material (i.e., firewood, bracken, gorse, plant litter) in the past, while former arable fields received this material.

Former arable soils show significantly higher $\mathrm{pH}$ values than continuous forest soils (Table 1). In $25 \%$ of the fields sampled in the former arable class surface soil mineral horizons have a $\mathrm{pH}$ over 6.0 and reach values up to 7.9 . Only $4 \%$ of the land on slopes less than $20 \%$ steep has a $\mathrm{pH}$ lower than 5.5 , whereas $81 \%$ has a $\mathrm{pH}$ of $6.5-7.5$, and $8 \%$ has a $\mathrm{pH}$ over 7.5. This high $\mathrm{pH}$ values are not consistent with the high amount of rainfall in the area, and show that farmers made an intense effort in liming arable fields, mostly located on the flatter areas of the county, up to the 1950s. As a result, the concentrations of exchangeable calcium and magnesium are also higher in former arable soils than in continuous forest soils (Table 1). Organic matter and $\mathrm{C} / \mathrm{N}$ ratio (ratio of organic carbon to nitrogen) values are significantly smaller in former arable soils than in continuous forest soils (Table 1), which suggests a slower mineralization rate of organic matter in the latter, while concentrations of Olsen phosphorus are significantly higher in former arable soils. 


\section{TABLE 1}

Comparison of mean values (with standard deviations) of various characteristics of the surface mineral horizons of soils currently under forest plantations in Lea-Artibai in relation to their land use in 1946

\begin{tabular}{|c|c|c|c|c|c|c|}
\hline $\begin{array}{l}\text { Land use } \\
1946\end{array}$ & $\mathrm{pH}$ & $\begin{array}{c}\text { Exch. Ca } \\
(\mathrm{cmol}(+) / \mathrm{kg})\end{array}$ & $\begin{array}{c}\text { Exch. Mg } \\
(\mathrm{cmol}(+) / \mathrm{kg})\end{array}$ & $\begin{array}{c}\text { Organic } \\
\text { matter (\%) }\end{array}$ & $\begin{array}{l}\mathrm{C} / \mathrm{N} \\
\text { ratio }\end{array}$ & $\begin{array}{c}\text { Olsen P } \\
\left(\mathrm{mg} \cdot \mathrm{kg}^{-1}\right)\end{array}$ \\
\hline Arable & $5.7(0.8)(n=33)$ & $10(3)(n=14)$ & $1.3(0.9)(n=14)$ & $3.9(1.3)(n=32)$ & $10(2)(n=29)$ & $7(6)(\mathrm{n}=31)$ \\
\hline Forest/shrubland & $4.4(0.6)(n=128)$ & $2(3)(n=53)$ & $0.5(0.5)(n=53)$ & $5.1(4.0)(n=125)$ & $13(3)(n=112)$ & $2(5)(n=121)$ \\
\hline$P$-value & $<0.0001$ & $<0.0001$ & 0.0001 & 0.008 & $<0.0001$ & $<0.0001$ \\
\hline
\end{tabular}

$P$-values according to Kruskal-Wallis test. Exch. Ca, Exch. Mg: exchangeable calcium and magnesium, respectively; $\mathrm{C} / \mathrm{N}$ ratio: ratio of organic carbon to total nitrogen; Olsen P: Olsen phosphorus. Source: our calculations from data in Olarieta (1993) and Olarieta et al. (2006).

In summary, soils of Lea-Artibai County (Bizkaia, northern Spain) show a polarization of nutrient concentrations between present and past arable fields and those fields that have always been used as forest or shrubland, and the common presence of horizons with very acid $\mathrm{pH}$ in the latter while the former frequently had basic $\mathrm{pH}$ or even calcareous reaction. This pattern in soil characteristics points at a long-lasting influence of the fertilization systems used before synthetic fertilizers were widely adopted. The relative enrichment of former arable soils suggests that they were fertilized in amounts over what crops required. But where did this fertilizer come from? In this paper we focus on the biomass and nutrients extracted from bracken and gorse fields, which were the basis of the fertilization system. We aim at quantifying the export flux at the field scale, and upscale our assessment to the whole county by estimating the area of those land use systems necessary considering different assumptions in relation to the fertilizer requirements.

\section{A LATE EXPANSION OF AGRICULTURE}

Up to the sixteentth century, the wet climate and narrow valleys in Bizkaia could only provide room for an agriculture based on cider apple orchards and shifting cultivation of small wheat fields growing among the apple trees, and therefore tithes were paid with apples or cider (Iturriza, 1885; Fernández Pinedo, 1974). These conditions allowed an extensive livestock production, mostly based on free-ranging pigs (Iturriza, 1885), that occupied the higher slopes of the county up to the thirteenth century (Fernández Albaladejo, 1975). But the forests and small ironworks dependent on them were the basis of the economy up to the end of the eighteenth century (Ainz, 2001). These ironworks first appeared in the higher areas, within forests that provided charcoal. In the fifteenth and sixteenth centuries iron production expanded to the valleys to make use of the hydraulic energy of 
rivers. Urzainqui (2007) suggests that the agricultural colonization of many of the valleys in the humid Basque Country did not take place until the ironworks descended from the hills into the valleys. But as Enríquez (1996) describes in the village of Aulestia, the owners of the ironworks dictated the use of the common and local land (i.e., that owned by the local council) all the way into the eighteenth century.

A significant agricultural sector emerged with the demographic expansion and creation of villages between the thirteenth and sixteenth centuries, as apple orchards and some forests were turned into arable wheat fields that may have been used under a form of shifting agriculture (Fernández Pinedo, 1974: 23; González Cembellín, 1990: 90; Aragón, 2015: 91). In the sixteenth century wheat substituted for apples as the currency for tithes (Fernández Pinedo, 1974; Ainz, 2001), but by the end of the century there was still little agriculture and the deficit in basic food grains was still covered, when possible, by imports from other regions in Spain, France, and England. Farmers were mostly part-timers as their basic job was in the ironworks (González Cembellín, 1990; Ainz, 2001).

In the fourteenth century, when English agriculture was already running out of land suitable for arable cultivation and showing signs of declining soil fertility (Newman \& Harvey, 1997), agriculture was only beginning to take off in Lea-Artibai County. In the village of Aulesti most of the farms date to the fifteenth century, and no new ones were founded after the end of the eighteenth century (Douglass, 1971).

\section{THE "MAIZE REVOLUTION"}

Maize only became a component of the human diet as important as wheat in the region in the middle seventeenth century, when crises in the trade, fishing and iron industries brought many workers back as full-time farmers (Ainz, 2001). The "maize revolution" involved the introduction of maize into crop rotations, and less so the opening of forest land for agriculture. Maize took the place of millet as the summer crop in the rotation, and was intercropped with beans. Three crops were obtained in two years, with forage crops (turnips, red clover, alfalfa, fenugreek) grown in the period between the harvest of wheat, which was frequently intercropped with broad beans, and the sowing of maize.

The new rotation considerably increased self-sufficiency in food production. Arizcun (1987) estimates that grain production in Bizkaia tripled between 1590 and 1775, and suggests that this was not so much the result of the conversion of forest land to agriculture as of the introduction of new crops and the transformation of swidden fields into permanent arable. But other authors state that during the first half of the eighteenth century 
much land was turned to arable and new farms established (SBAP, 1768), and Fernández Albaladejo (1975) dates back to 1780-90 the main thrust of the conversion of forest land into permanent arable. The Abbey of Ziortza, probably the largest landowner in LeaArtibai County, leased part of its land in emphyteutical contracts between 1740 and 1777 and again in the 1850s (Fernández Pinedo, 1974).

This conversion to new arable land produced many conflicts in the eighteenth century both with foresters and with already settled-farmers who could no longer make use of the land to collect the different plant materials they needed (Fernández Pinedo, 1974). The two year-rotation required an intense fertilization regime based on the extraction of basabera (bracken, gorse, and plant litter) from shrub and forest land. Bracken and plant litter were used as fertilizers after composting or after being used as bedding for animals and subsequently applied to the fields mixed with dung. Gorse was mostly used to fuel the kilns that produced the lime required to amend soil acidity. Furthermore, some farmers, in order to correct the shallow and weak nature of their soils, bring soil from chestnut tree forests and other forests considered of superior quality (SBAP, 1768: 32). Garagarza (1859: 7-8) wrote that dung from animals are but a small fraction of the fertilizers, and extractions from the hills are the tributaries of the system... we cannot completely dispose of 'basabera', even if it is just to obtain the litter and bracken indispensable for animal bedding; but this extremely deleterious practice for tree growth should diminish considerably.

Historical references describe farms in the humid Basque Country as having 1.0-1.3 ha of cropland (3-4 fanegas $^{2}$ ) (SBAP, 1768: 164; Unamuno, 1896: 75; Vicario, 1901: 192). For Lea-Artibai County in the 1860s, we have estimated the area of cropland from the data on production of wheat and maize in the townships (Lorenzo, 1996: 88) and considering the yields obtained in the township of Aulesti in 1867, $800 \mathrm{~kg}$ of wheat and 1,200 $\mathrm{kg}$ maize per hectare (Enríquez, 1996) (Table 2). The result is 1,598-1,696 ha of wheat and 1,654-1,698 ha of maize, for a total of 3,200-3,400 ha of cropland. To this figure we should add the small portions of land with permanent grassland, which last for 6-7 years (Madoz, 1990: 223). Considering the proportion between cropland and managed grasslands suggested by Trueba (1956), the latter would amount to 800-850 ha in Lea-Artibai. The $3,200-3,400$ ha of cropland in the 1860 s amount to $11 \%$ more than the total area in the county that has a slope of less than $20 \%$, which means that a significant proportion of this land was under a high risk of water erosion.

Cropland had probably increased in the county since the eighteenth century. Data collected by Agirreazkuenaga $(1987: 24)$ for the whole province of Bizkaia suggest that pro-

2. We have considered 1 fanega as equivalent to 0.33 ha (CARRIÓN, 1996). 
duction of wheat and maize increased by $40 \%$ between 1773 and 1850 and by $28 \%$ between 1850 and 1876. Wheat and maize production in the township of Amoroto tripled in the eighteenth century. In the early nineteenth century there was a clear decrease in the production of both crops but by the 1860 s production had returned to levels similar to those of 1780-1800. In the township of Markina, on the other hand, production of both crops multiplied by a factor of 2.4 between 1800 and 1860 (Lorenzo, 1996: 87). For the whole of Lea-Artibai County we estimate an increase of $23 \%$ in production in this period, and we suggest that this increase up to the 1860 s was mostly the result of land being converted into arable.

Gogeascoechea (1993) estimates that the proportion of forested land in each village in 1804 varied between $1 \%$ in Ziortza, 9\% in Munitibar, $15 \%$ in Aulesti, $21 \%$ in Ispaster, $23 \%$ in Mendexa, $27 \%$ in Gizaburuaga, and $59 \%$ in Amoroto, with an average of $22 \%$. Extrapolating this proportion to the whole county suggests Lea-Artibai had about 4,600 ha of woodland in the early nineteenth century. If we consider that the expansion of agriculture between 1800 and 1860 took place at the expense of this woodland, about 600 ha would have been converted to arable in this period.

TABLE 2

Yields of wheat and maize $\left(\mathrm{kg} \cdot \mathrm{ha}^{-1}\right)$ reported in various locations in the Basque Country from the eighteenth to the twentieth centuries

\begin{tabular}{lrrrrrr}
\hline Year & \multicolumn{2}{c}{ Wheat } & \multicolumn{3}{c}{ Maize } \\
& \multicolumn{1}{c}{ Mean values } & 1st class soils & Thin soils on slopes Mean values & 1st class soils & Thin soils on slopes \\
\hline $1768^{*}$ & 1,050 & - & - & 1,580 & - & - \\
$1771^{2}$ & $1,000-1,200$ & - & - & - & - & - \\
$1790 s^{2}$ & 1,400 & - & - & - & - & - \\
$1802^{2}$ & - & 1,440 & 520 & - & 1,970 & 1,180 \\
$1859^{3}$ & - & 1,848 & 1,230 & - & 2,640 & 1,320 \\
$1867-68^{4}$ & 824 & & & 1,200 & & - \\
$1900^{5}$ & - & - & - & 1,440 & - & - \\
$1904-33^{6}$ & 807 & - & - & 595 & - & - \\
\hline
\end{tabular}

Sources: 1. for the humid region of the Basque Country (SBAP, 1768: 164); 2. for various townships in the humid region of the Basque Country (Fernández Pinedo, 1974: 213-15); 3. for the humid region of the Basque Country (Garagarza, 1859: 4); 4. for the township of Aulestia (Enríquez, 1996: 354); 5. for Bizkaia (Larrea,1900, cited by Gogeascoechea, 1994: 93); 6. for Bizkaia (Anuario de Estadística Agraria, http://www.mapama.gob.es/app/biblioteca-virtual/articulos-de-revistas/rev_numero.asp?codrevista).

According to Fernández Pinedo (1974: 223) the number of animals in the farms was small, in Oñate, in 1775 [...] there was a mean of 3.37 oxen, cows, and heifers per farm [...] In Orozco, this value reached 5.54, and they spent most of the year, about seven months, 
grazing in communal land except for a couple of oxen, a cow, and a few pigs that remained on the farm. While a significant decrease in the number of farm animals must have occurred between 1790 and 1839 due to the various wars and the expansion of arable land (Lanza, 1996), numbers recovered quickly (Fernández Pinedo, 1974).

According to the 1865 census (Table 3), and considering the live weights proposed by Flores de Lemus (1976), the total live weight (LW) of farm animals in Lea-Artibai amounted to $3,768 \mathrm{Mg}$, cattle and sheep accounting for $79 \%$ and $12 \%$, respectively, of this amount. In the most common case, a farm had 2 cows or oxen plus 2 heifers. Only three farms had over $7 \mathrm{Mg} \mathrm{LW}$, equivalent to over 19 cows, and $50 \%$ of the 50 farms with the highest LW in the county had the equivalent of just 8-9 cows $^{3}$. Maintenance of these animals would have required $2,650-3,843$ ha of unfertilized permanent grasslands ${ }^{4}$.

Between 1865 and 1929 there was a slight increase in the total LW of animals in the province of Bizkaia. For the 1950s, Trueba (1956) considered a typical farm in this area of Bizkaia to have 4 Livestock Units ${ }^{5}$ that produced 60 carts of dung (about $6 \mathrm{Mg}$ ).

\section{THE DEMISE OF AGRICULTURE}

The demand for basabera increased during the middle of the eighteenth century, and some local councils terminated free access to this resource and established regulations for its use. Gathering basabera caused problems for the forest, as tree seedlings might have been affected by cutting or trampling by carts, while on the other hand, farmers complained when forest plantations shaded out bracken (Aragon, 2001: 64), and some villages disallowed bracken harvesting for the first three years in new forest plantations. Even the collection of dung deposited by grazing animals in common land came to be regulated in some villages in Bizkaia (Arregi, 1984).

3. Archivo Histórico Foral de Bizkaia, Administración de Bizkaia, Sector Primario, Industria y Comercio, Ganadería, reg. 34, leg. 2. "Censo de ganadería, n. ${ }^{\circ}$ 34, Estadística, Resumen general por partidos judiciales y ayuntamientos, del número de ganado de todas las clases existentes en este Señorío”, 1865.

4. Estimated considering the number of farm animals (Table 2); a requirement of $5 \mathrm{UF}^{- \text {day }^{-1} \text { per }}$ $525 \mathrm{kgLW}$, with $1 \mathrm{UF}$ being equivalent to the net energy in $1 \mathrm{~kg}$ of barley; a yield of 2,300-3,300

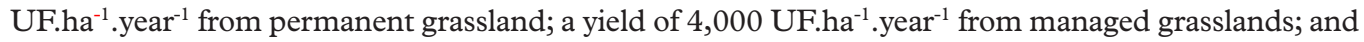
a yield of 350 UF.ha $^{-1}$.year ${ }^{-1}$ from crop straw (UF: unidades forrajeras, fodder units; $1 \mathrm{UF}=$ the net energy of $1 \mathrm{~kg}$ of barley).

5. A Livestock Unit is equivalent to a dairy cow. 


\section{TABLE 3}

Number of farms with animals, animals of different types, and estimated fraction of time that these animals spent in the barns in Lea-Artibai County, 1865

\begin{tabular}{lcccccccc}
\hline & \multicolumn{2}{c}{ Cattle } & Horses \& & Mules & Sheeps & Goats & \multicolumn{2}{c}{ Pigs } \\
& $<\mathbf{3 0}$ months & $>\mathbf{3 0}$ months & donkeys & & & & $<\mathbf{6}$ months & $>\mathbf{6}$ months \\
\hline Number of farms & 1,815 & 158 & 340 & 763 & 199 & 1,183 & & \\
Number of animals & 4,843 & 4,473 & 326 & 586 & 1,557 & 15,258 & 754 & 1,563 \\
Time spent indoors & $10 / 12$ & $10 / 12$ & $5 / 12$ & $5 / 12$ & $12 / 12$ & $5 / 12$ & $5 / 12$ & $10 / 12$ \\
\hline
\end{tabular}

Source: Archivo Histórico Foral de Bizkaia, Administración de Bizkaia, Sector Primario, Industria y Comercio, Ganadería, reg. 34, leg. 2. "Censo de ganadería, n. ${ }^{\circ}$ 34, Estadística, Resumen general por partidos judiciales y ayuntamientos, del número de ganado de todas las clases existentes en este Señorío”, 1865.

Between 1905 and 1926 there was an increase of $64 \%$ in the area used in Bizkaia for wheat or maize, the two main crops (Figure 1). The 1920-50s period marks the maximum expansion of arable land in the province, and the interpretation of the aerial photographs of Lea-Artibai County from 1946 produces an estimate of 5,059 ha of this land use, of which 3,413 ha were on slopes over $20 \%$, and 7,140 ha of forests. For the 1950s, Trueba (1956) defines the average farm in the eastern part of Bizkaia as having, forest plantations aside, about 4.5 ha, 2.0 ha as arable, 0.5 ha of grassland, and 2 ha of bracken and gorse fields.

We estimate that the rates of application of synthetic fertilizers reached $34 \mathrm{~kg} \cdot \mathrm{ha}^{-1}$ in 1919 and $45 \mathrm{~kg} \mathrm{ha}^{-1}$ in $1928^{6}$. After the 1936-39 Civil War, use of these fertilizers had increased in the 1940 s to around $180 \mathrm{~kg}^{-} \mathrm{ha}^{-1}$, and by the $1950 \mathrm{~s}$ rates of application would have reached $334 \mathrm{~kg} \cdot \mathrm{ha}^{-1}$ (Trueba, 1956).

Therefore, while current arable fields in Lea-Artibai receive heavy applications of manure and synthetic fertilizers, as recorded in interviews with the farmers, the relatively high $\mathrm{pH}$ and nutrient concentration in the arable-turned-forest fields (Table 1) cannot be attributed to the use of lime or synthetic fertilizers in the past 70 years. None of these products is applied in forest plantations; lime use was mostly discontinued, for all purposes, in the county between 1930 and 1950; and the limited use of synthetic fertilizers up to the Civil War was insufficient to have produced such characteristics.

6. Estimated from data on the use of fertilizers in the Basque Country (http://www.ine.es/inebaseweb/pdfDispacher.do?td=148522; http://www.ine.es/inebaseweb/pdfDispacher.do?td=82256) and the area of arable land in Bizkaia (Lanza, 1996). 
FIGURE 1

Evolution of the area of main crops (ha) in Bizkaia, 1900-80

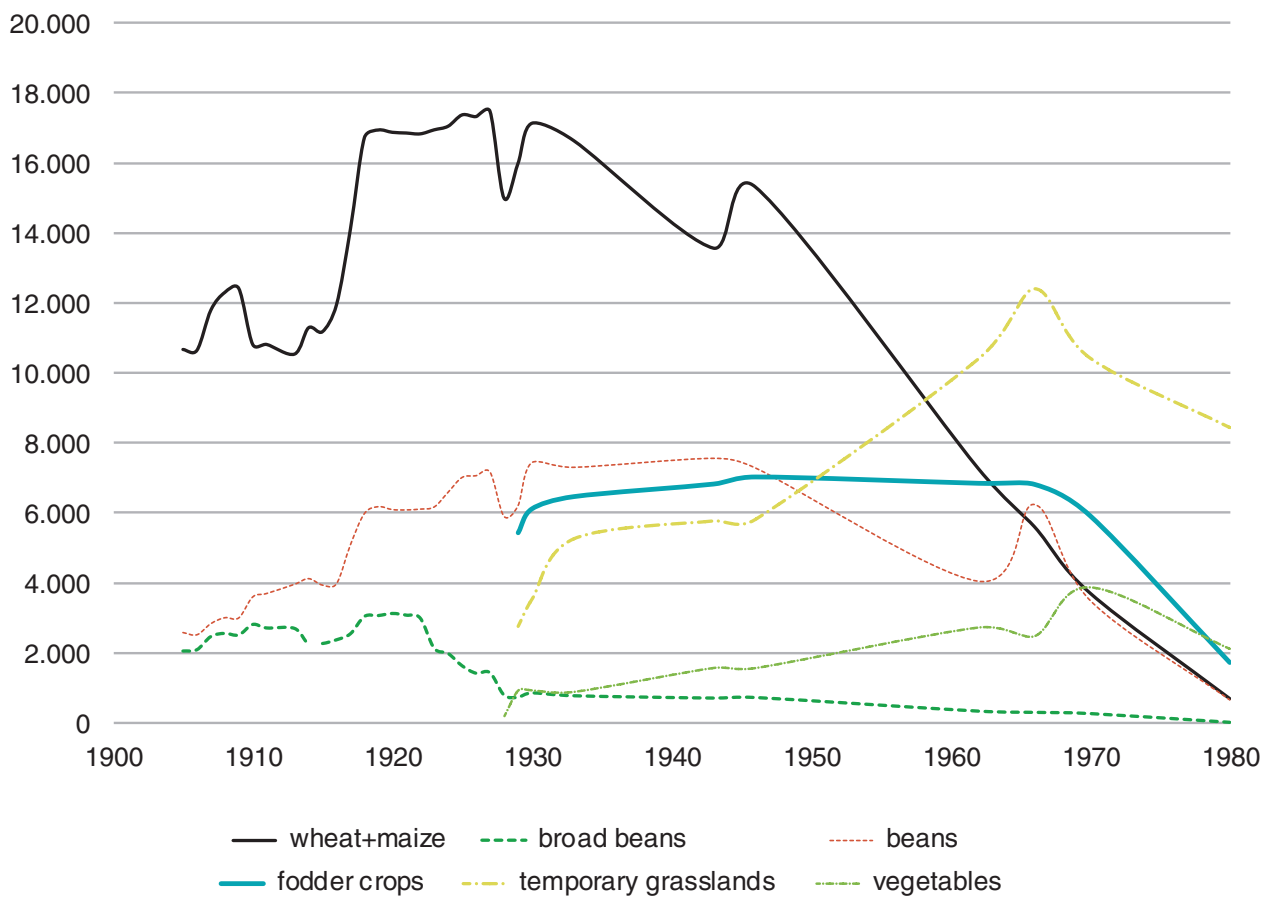

Source: Anuario de Estadística Agraria, http://www.mapama.gob.es/app/biblioteca-virtual/articulos-de-revistas/rev_numero.asp?codrevista

\section{LIMING AND HARVESTING OF GORSE}

The conversion of forest and shrubland into arable and the new two year-rotation brought about the widespread use of lime to decrease soil acidity, which became so popular that some writers warned about its overuse in some soils. As the optimum $\mathrm{pH}$ for most of the crops produced is 5.5-6.0 (Rowell, 1988), it is clear from Table 4 that the former arable fields with $\mathrm{pH}$ over 6.0 were subject to overliming.

SBAP (1768) suggests that the general use of lime emerged during the first half of the eighteenth century. Almost every farm had its own lime kiln (Laffite, 1919) that required a lot of work and expense in firewood (Larramendi, 1985: 64). Tenancy agreements frequently included the duty of liming in the first year (López Musatadi, 1998: 52). Caro Baroja (1986: 80) refers to an agreement from the early nineteenth century in which tenants had to burn a lime kiln every year to produce 50 carts of lime (about $24,000 \mathrm{~kg}$ ) to fertilize 8.2 ha. The use of lime in Ireland in 1800-40 was also excessive, often amounting 
to the equivalent of 10 tons ground limestone per statute acre: in the light of modern knowledge regarding the ill effects of overliming, it is obvious that crop production must frequently have been seriously impaired by this practice (Walsh, Ryan \& Kilroy, 1957: 106).

The decreased availability of firewood in the Basque Country also meant that burning lime kilns was increasingly difficult by the late eighteenth century, and the use of marls, which do not require burning, was proposed as an alternative (SBAP, 1768). According to this source, there was some debate about the appropriateness of marl as a fertilizer, or whether it was suitable for the clayey soils of the region. The debate was opposite to that going on in Britain, where marling was used first, probably because of its higher suitability for the coarser-textured soils, and liming only entered the picture when cheap supplies became available (Mathew, 1993).

In the Basque Country, arable land was limed every nine years as general practice in the eighteenth century, but by the second half of the nineteenth century the period was shortened to every 2-3 years (Larramendi, 1985; Laffite, 1919; Olazábal, 1857). Lime kilns required about $100 \mathrm{Mg}$ of firewood to produce $60 \mathrm{Mg}$ of quicklime from $100 \mathrm{Mg}$ of limestone (Lange, 1996). But between the 1930s and 1950s, most kilns were abandoned in Bizkaia, the use of lime was discontinued, even in limestone areas, and synthetic fertilizers became the norm (Arrillaga, 1960; Douglass, 1977).

The firewood used in lime kilns was mostly obtained from the branches and roots of gorse (Ulex gallii Planch. and Ulex europaeus L.) (Caro Baroja, 1986). The heavy use of gorse for lime kilns may explain why this species does not appear in dense stands in LeaArtibai, even though it is pervasive in nearby Galiza (northwestern Spain), where the minimal presence of limestone rocks and lime kilns, and the integration of gorse in the agricultural system (Corbacho, 2017) allowed the shrub to spread widely. In Galiza it was also used as bedding material and afterwards, incorporated into the manure, as fertilizer on arable fields (Balboa \& Fernández Prieto, 1996).

In the Basque Country gorse fields were cut every 9 years (Aragón, 2001: 95). Gorse

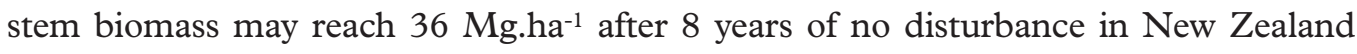
(Egunjobi, 1971). Considering the nutrient concentrations in this material (Augusto et al., 2009), the harvest of that amount of biomass would extract 104-187 kg N.ha-1, 3-6 kg P.ha-1, 44-79 kg K.ha-1, 18-32 kg Ca.ha-1, and 12-22 kg Mg.ha-1 ${ }^{-1}$ Considering the inputs from weathering of the underlying rock and from atmospheric deposition, this extraction alone produced a negative budget of phosphorus. It also produced an acid load of 0.8-1.7 $\mathrm{kg} \mathrm{H}^{+}$.ha-1.year ${ }^{-1}$, which would have required the application of 40-80 kg $\mathrm{CaCO} 3$. ha $^{-1}$.year ${ }^{-1}$ to be neutralized. 
Lime was required in two situations. A single application, may be spread in a few years, was required when converting land from forest or shrubland to arable to increase the soil $\mathrm{pH}$ from the very acidic conditions dominant in the former. And yearly amounts were applied afterwards to maintain the increased $\mathrm{pH}$. The application of lime in the first case would have also produced a much higher availability of nutrients for crops during the early years of cultivation as a higher $\mathrm{pH}$ produced a quicker mineralization rate of the organic matter accumulated under the previous forest or shrub vegetation.

We hypothesize that fields turned to arable from forest or shrubland in the study period had a $\mathrm{pH}$ of about 5.0 in the surface mineral horizon, and that their current $\mathrm{pH}$ is mostly the result of liming during that period. We have estimated the amount of lime required to change the $\mathrm{pH}$ of the surface mineral horizons to their current $\mathrm{pH}$ using the buffer curves of these soils (Table 4). And the lime required to maintain the $\mathrm{pH}$ of soils in arable fields has been estimated considering the amounts suggested by Rowell (1988) according to soil $\mathrm{pH}$ and considering that rainfall in the county produces $700 \mathrm{~mm}$ of drainage water (Table 4).

\section{TABLE 4}

Area of soils with different $\mathrm{pH}$ in the surface mineral horizon in Lea-Artibai county and their lime requirements to reach and maintain current $\mathrm{pH}$

\begin{tabular}{|c|c|c|c|}
\hline $\begin{array}{l}\text { Soil } \\
\text { pH }\end{array}$ & $\begin{array}{l}\text { Area } \\
\text { (ha) }\end{array}$ & $\begin{array}{l}\text { Lime required to increase } \mathrm{pH} \\
\text { from } 5.0\left(\mathrm{Mg} \mathrm{CaCO} . \mathrm{ha}^{-1}\right)\end{array}$ & $\begin{array}{l}\text { Lime required to maintain } \\
\mathrm{pH}\left(\mathrm{Mg} \text { CaCO3.ha-1. } \mathrm{y}^{-1}\right)\end{array}$ \\
\hline $5.0-5.5$ & 1,012 & 0 & 0.35 \\
\hline $5.5-6.5$ & 1,223 & 14 & 0.70 \\
\hline $6.5-7.5$ & 2,249 & 32 & 1.40 \\
\hline$>7.5$ & 184 & 96 & 2.80 \\
\hline
\end{tabular}

Source: our estimates based on Olarieta (1993).

Approximately 2,700-4,900 ha of gorse fields would have been harvested to obtain the firewood required to burn the lime necessary to increase the $\mathrm{pH}$ of fields upon conversion to arable. Another $225-400$ ha would have been cut for yearly maintenance of arable fields, and considering the 9 year-fallow period required for gorse production, it means that 2,000-3,600 ha of gorse fields would have been involved in obtaining this lime.

\section{THE INSTITUTION OF BRACKEN FIELDS}

Bracken (Pteridium aquilinum [L.] Kuhn) is a fern species that sheds its aerial biomass every autumn but the buds in rhizomes produce new fronds that fully cover the ground 
under open conditions. Dry bracken has slightly less water retention capacity than straw (Aguirre, 1945). Bracken fields became indispensable for the maize revolution, and even as late as the 1950s bracken fields play a fundamental role in the rural economy (Douglass, 1977: 63). Arburu (1956) stated that farmers know perfectly well that their harvests depend on having animals in order to have fertilizer and on having bracken fields to produce this fertilizer.

Each farm had its own bracken fields, and in some villages it was also assigned a bracken field in the common land, the limits of which were defined by the farm's land title (Caro Baroja, 1986). In Baztan County, each farmer was allowed to claim individually a maximum of 2.3 ha in the common land (Arizcun, 1988). This assignment was for an indefinite period of time in some places, while in others it was for only five years due to high demand in the early twentieth century (Urzainqui, 2007). Access to bracken fields and basabera in common land was free in many cases until the eighteenth century (Fernández Pinedo, 1974) and remained so in villages with extensive areas of bracken (e.g. Ziortza) (Unamuno, 1896). In other places bracken harvesting was a communal affair regulated by local and/or provincial norms (Vicario, 1901). Bracken harvesting was not allowed before early September in general, particularly in townships with smaller areas of shrubland (e.g. Munitibar). A maximum number of people per family was allowed to work during a strictly defined period of time, usually $8-10$ days, and only specific cutting tools were allowed (Unamuno, 1896; Caro Baroja, 1986; Otaegui, 1984; Arizcun, 1988). The amount of basabera collected was also fixed in many cases (Unamuno, 1896), e. g., 3 carts of litter (about 1,200 kg) and as much bracken as farmers could cut in the village of Iurre, or up to 6 carts (about 2,400 kg) in Getxo. By the end of the nineteenth century some villages started auctioning off bracken fields in the face of increasing demand.

The significance of the extraction of bracken and litter may be inferred from the income obtained by local councils in Lea-Artibai in the late eighteenth and early nineteenth centuries, which amounted to $16-25 \%$ of the total revenue they obtained from leasing various assets (Martínez Fernández, 1993: 81; López Musatadi, 1998: 106). In the 1950s, the price of bracken was estimated at 0.30 pesetas. $\mathrm{kg}^{-1}$ (Trueba, 1956; Greenwood, 1976).

The yield of bracken fields was $2,256 \mathrm{~kg}$ per hectare of fibres convertible to humus (Arburu, 1956). If we consider this to mean organic carbon, the figure is similar to that obtained by Olarieta et al. (2007) in Lea-Artibai, $2,100 \mathrm{~kg}$ ha $^{-1}$, equivalent to a yield of 4,400 $\mathrm{kg}$ of dry matter (DM) per hectare. Trueba (1956) also reported figures of 4,400-4,500 $\mathrm{kg} \mathrm{DM} \cdot \mathrm{ha}^{-1}$. A survey of various fields in the Basque Country offered figures reaching up to 6,000 kg DM.ha-1 (Miñana, 1980). 
The nutrients extracted in 4,400 kg DM amount to 47-58 kg N.ha-1, 3-11 kg P.ha-1, 40-58 kg K.ha- ${ }^{-1}$, 13-19 kg Ca.ha-1, 8 kg Mg.ha ${ }^{-1}$, and 2 kg S.ha $^{-1}$ (Arburu, 1956; Olarieta et al., 2007). This extraction alone produced a negative budget of nitrogen, phosphorus and potassium, and would have also produced an acid load of $6 \mathrm{~kg} \mathrm{H}^{+}$. ha- ${ }^{-1}$.year-1 that would have required the application of $300 \mathrm{~kg} \mathrm{CaCO} 3 . \mathrm{ha}^{-1}$.year-1 to be neutralized, or otherwise it would decrease soil $\mathrm{pH}$ from a value of 5.0 to a value of 4.0 in about 110 years.

\section{HOW MUCH BRACKEN WAS COLLECTED?}

There is no explicit data about the amount of bracken collected by farmers in LeaArtibai in the study period. We have approached this issue by considering the bedding requirements of farm animals as the minimum needed, considering the number of animals in the county (see Section 4), their bedding requirements, and the yield of bracken fields. Estimates of annual bedding requirements are $180 \mathrm{~kg}$.ewe ${ }^{-1}$.year ${ }^{-1}, 1,000 \mathrm{~kg} \cdot \mathrm{pig}^{-1}$.year ${ }^{-1}$, and 1,400 kg.cow or horse ${ }^{-1}$.year-1 (Cascón, 1918). Greenwood's estimate (1976) of only $694 \mathrm{~kg}$ of bracken per cow may be related to the evolution in barn type and management. We have used Cascón's data taking also into account the amount of time that each type of animal was kept indoors (Table 3). Based on these numbers and the 1865 census, 3,541 ha of bracken fields were required every year to obtain the bedding material for farm animals.

Similar calculations considering the average LW in farms of Lea-Artibai suggest that they required about 7.4 Mg of bracken from about 2 ha of bracken fields. About 20 hours of work were required to harvest 1 ha of bracken according to old farmers (Pedro Aizpurua, personal communication), and those farms therefore would have required 4-5 days to harvest the bracken required for their animals. This is much less than the period allowed in most villages. Even the big farms with the equivalent of 8-9 cows would have required only 6-7 days.

Some of the harvested bracken was not used for bedding at all. According to a 1754 source, farmers

are allowed to collect bracken from September onwards in common land; they bring it home, and either in the barns or outside the house, in paths and ditches, they let it to rot and produce manure. They also take great care to collect the dry leaves fallen from the trees, bring them in carts and let them rot, which happens very easily (Larramendi, 1985: 63). 
Therefore, bracken harvesting was driven by the fertilization as much as by the bedding requirements of farms. In Galiza (northwestern Spain) a similar process was applied to gorse, and all tasks involved in producing manure would amount to $20 \%$ of the total labour in the farm (Balboa \& Fernández Prieto, 1996).

In Lea-Artibai, the three course-rotation involved manuring each crop (SBAP, 1768; Vicario, 1901; Laffite, 1918), i. e., three applications every two years. Managed grasslands were also manured once a year (Douglass, 1977). Therefore, each year the equivalent of 5,800 ha were manured in the 1860 s. The manure obtained from the animal excreta and bedding material would have provided $7,355 \mathrm{~kg} \cdot \mathrm{ha}^{-1} \mathrm{year}^{-1}$.

The upper limit of the amount of bracken collected by farmers may be established from the rarely-achieved traditional recommendation of $10 \mathrm{Mg} \cdot \mathrm{ha}^{-1} \mathrm{year}^{-1}$ of manure. To achieve this amount, and further from the 7,355 kg.ha- $\mathrm{year}^{-1}$ collected in the barns, the remaining 2,645 kg.ha-1year-1 would have required a further 4,101 ha of bracken fields, on top of the 3,541 ha needed to obtain the bedding material (Table 5).

In the early twentieth century, and considering the same animal LW in Lea-Artibai as in 1865 and 4,000 ha of arable land, the manure available to fertilize this land was 5,884 $\mathrm{kg} \cdot \mathrm{ha}^{-1}$.year ${ }^{-1}$. Another 7,043 ha would have been required to achieve $10 \mathrm{Mg} \cdot \mathrm{ha}^{-1} \mathrm{year}^{-1}$ of manure to fertilize that amount of arable land (Table 5).

\section{A "FERTILIZER CRISIS": WAS THERE ENOUGH BASABERA IN LEA- ARTIBAI?}

The pressure on firewood from lime kilns was already a matter of concern in 1711 in other areas in the Basque Country (Arizcun, 1988), and the SBAP complained about the shortage of fertilizers:

the tragedy is that the same emphasis that farmers have put in obtaining this treasure [fertilizer] (as this is how they quite rightly call it) has cleaned all the fields, in such way that pastures, bracken, litter, and the gorse required to burn the lime kilns have notably decreased. So much so, that some farmers have not been able to collect, whatever the price, the few carts of manure they required for their home garden (SBAP, 1768: 31).

The extraction of basabera intensified later on, eventually leading, according to various authors, to a "fertilizer crisis" in the early nineteenth century in the region (Olazábal, 
1857; Fernández Albaladejo, 1975). Such crisis also appeared in other regions of Spain in the late nineteenth century (González de Molina et al., 2015). In the early twentieth century Laffite (1918) recorded complaints of farmers the Basque Country in relation to the diminishing availability of both bracken and gorse for bedding. But was there enough basabera resources in Lea-Artibai County to cope with the expanding agriculture? We have approached this question by considering whether the county could have accommodated all land uses in the study period.

\section{TABLE 5}

Area (ha) covered with different land uses in Lea-Artibai County in the 1860s and in the first decades of the twentieth century

\begin{tabular}{|c|c|c|c|}
\hline \multirow{2}{*}{\multicolumn{2}{|c|}{ Rock outcrops ${ }^{1}$}} & $1860 s$ & $1910-30$ \\
\hline & & 403 & 403 \\
\hline \multicolumn{2}{|l|}{ Built up ${ }^{1}$} & 174 & 174 \\
\hline \multicolumn{2}{|l|}{ Cropland } & $3,200-3,400$ & $4,000^{2}$ \\
\hline \multicolumn{2}{|l|}{ Managed grassland } & $800-850$ & $1,000^{3}$ \\
\hline \multicolumn{2}{|c|}{ Permanent grassland } & $2,650-3,843$ & $2,550-3,650$ \\
\hline \multicolumn{2}{|c|}{ Forest } & 4,000 & $5,000^{2}$ \\
\hline \multicolumn{2}{|l|}{ Gorse $^{4}$} & $2,000-3,600$ & $2,000-3,600$ \\
\hline \multicolumn{2}{|l|}{ Bracken available ${ }^{5}$} & $4,314-7,357$ & $3,023-5,674$ \\
\hline & Bedding $^{6}$ & 3,541 & 3,541 \\
\hline \multirow[t]{2}{*}{ Bracken required } & Crop extractions ${ }^{7}$ & 3,765 & 6,673 \\
\hline & Optimum manuring ${ }^{8}$ & 7,642 & 10,584 \\
\hline
\end{tabular}

Sources: 1: estimated from the interpretation of the 1946 aerial photographs; 2 : estimated as the mean value between the area in the 1860 s and in 1946; 3: estimated as $25 \%$ of the arable land (Trueba, 1956); 4 : considering only the gorse fuelwood required to produce lime for yearly soil $\mathrm{pH}$ maintenance; 5 : calculated by subtracting the land covered with all the other land uses from the total area of the county $(20,584 \mathrm{ha}) ; 6$ : area of bracken fields required to obtain the bedding for farm animals considering the same number and type of farm animals in 1910-30 than in the 1860s; 7: area of bracken fields required to obtain $7500 \mathrm{~kg}^{-\mathrm{ha}^{-}}$ ${ }^{1}$.year ${ }^{-1}$ of manure for the arable land; 8: area of bracken fields required to obtain 10,000 kg.ha-1. year-1 of $^{-1}$ manure for the arable land.

Table 5 summarizes the estimated amount of land occupied by the various land uses in Lea-Artibai County in the 1860 s and in the first decades of the twentieth century, the area that would have been left for bracken fields, and the area of bracken fields required to achieve different targets, i.e., the bedding requirements of farm animals, the extractions by crops ${ }^{7}$, or the "optimum manuring" of $10 \mathrm{Mg} \cdot \mathrm{ha}^{-1} \mathrm{year}^{-1}$.

7. GARAGARZA (1859-1861: 61) estimated that $7.5{\mathrm{Mg} \cdot \mathrm{ha}^{-1} \text {.year }}^{-1}$ of manure were required to compensate for the extractions by crops. 
In the 1860 s, the availability of bracken at the county scale would have been able to provide enough material to produce, together with animal excreta, the amount of manure sufficient to fertilize arable land over the "crop requirements". But by the early decades of the twentieth century bracken fields could not be the only source of fertilizing material for arable land as they would have hardly been able to supply the bedding requirements of farm animals. Extensive extraction of bracken and litter from forests and gorse fields would have been required, but at a high cost for the source ecosystems, both in terms of vegetation dynamics and in relation to their nutrient stocks.

Planting of forest trees by individual farmers was allowed, and promoted, on local land in order to maintain the forest area, and these farmers had the right to collect the litter and shrubs under their trees (Vicario, 1901). Harvesting of undergrowth in forests was therefore a very common practice (Iturriza, 1885; Larramendi, 1985) and thought to be one of the main reasons for their poor regeneration and general decline (Olazábal, 1857; Garagarza, 1859).

Furthermore, the extraction of bracken, gorse, and litter surely had significant consequences on shrublands (Watt, 1956): cutting of bracken in autumn has a very small effect on regrowth during the next season, but by limiting the amount of litter produced may slowly decrease its yield; and bracken availability may have also decreased through time as it was left on the thinner soils where its yields are smaller and the deeper soils were turned to agriculture or grassland.

The fertilizer crisis reported by various authors may have been related to a shortage of manure, but certainly other factors also played their part, including the decline in the mineralizing effect of lime on the organic stocks of nutrients in the soils, the erosion in the steep arable fields, and the emergence of the shallow nature of most soils in LeaArtibai ( $75 \%$ of former arable soils are less than $50 \mathrm{~cm}$ deep) as a limiting factor for maize production (Olazábal, 1857).

\section{CONCLUSIONS}

The maize revolution in the eighteenth and nineteenth centuries in Lea-Artibai County, and in the humid Basque Country in general, was based on a process of nutrient concentration in agricultural fields, consistent with the concept of "concentrational agriculture" proposed by Christiansen (1996), that required the depletion of nutrients and acidification of soils in shrubland through the collection of bracken, gorse, and plant litter in order to produce the manure and lime required for arable fields. The area re- 
quired to produce these plant materials was equivalent to $150-200 \%$ of the area of cropland.

The "bracken economy" described here reveals that agriculture in general imposes a double metabolic rift: a general one between human settlements (and their sinks of residues) and agrarian systems, and a subordinate one between the cultivated soils of these systems and the ecosystems that act as their sources of nutrients. The different modes of concentrational agriculture represent the specific ways in which societies coped with the metabolic rift and passed it on to their sources of plant nutrients by using different nutrient carriers (e.g., the animals bringing manure from the outfield, the plant material collected directly from this outfield).

\section{ACKNOWLEDGEMENTS}

This work was supported by the Social Sciences and Humanities Research Council of Canada research project SFS 895-2011-1020 and by the Spanish Government research project HAR2015-69620-C2-1-P. We thank Marina Tripiana and Guzmán López for their GIS work, and Geoff Cunfer, Bea Corbacho, Enric Saguer, and the anonymous reviewers of Historia Agraria who provided helpful comments on a previous version of this paper.

\section{REFERENCES}

AgIRREAZKuenaga, J. (1987). Vizcaya en el siglo XIX (1814-1876): Las finanzas públicas de un Estado emergente. Leioa: Euskal Herriko Unibertsitatea.

AguirRe, J. (1945). Vulgarización de abonos. Madrid: Ministerio de Agricultura.

AINZ, M. J. (2001). El caserío vasco en el país de las industrias. Madrid: Ministerio de Agricultura, Pesca y Alimentación.

Altieri, M. A. (2004). Linking Ecologists and Traditional Farmers in the Search for Sustainable Agriculture. Frontiers in Ecology and the Environment, 2 (1), 35-42.

ARAGÓN, A. (2001). El bosque guipuzcoano en la Edad Moderna: Aprovechamiento, ordenamiento legal y conflictividad. Munibe. Suplemento, (14).

ARAGÓN, A. (2013). El impacto de las dificultades económicas y climáticas durante el siglo XVII en el sector agropecuario guipuzcoano. XIV International Conference of Agricultural History. Badajoz, 7-9 November.

ARAGÓN, A. (2015). El sector agrario guipuzcoano en la encrucijada de los siglos XVI y XVII. Lurralde: Investigación y Espacio, (38), 89-116. 
Arburu (J. M. Sansinea) (1956). Sobre la fórmula agrícola en el País Vasco. Munibe, Ciencias Naturales-Natur Zientziak, 8 (1), 44-9.

ARIzCun, A. (1987). El sector agropecuario de la Euskalherria peninsular durante el Antiguo Régimen. Ekonomiaz, 9-10 (4), 13-34.

Arizcun, A. (1988). Economía y sociedad en un valle pirenaico del Antiguo Régimen: Baztán, 1600-1841. Pamplona: Gobierno de Navarra/Institución Príncipe de Viana. Arnáez, J., Lasanta, T., Errea, M. P. \& Ortigosa, L. (2011). Land Abandonment, Landscape Evolution, and Soil Erosion in a Spanish Mediterranean Mountain Region: The Case of Camero Viejo. Land Degradation E Development, 22 (6), 537-550.

ARREGUI, G. (1984). Funciones de la cofradía en las anteiglesias de Bizkaia: Siglos XVIII y XIX. In IX Congreso de Estudios Vascos (pp. 353-57). Bilbao: Eusko Ikaskuntza.

ARRILlaga, S. (1960). Contribución al estudio etnográfico del pueblo de Elorrio (Vizcaya): Año 1958. Anuario de Eusko Folklore, (17), 89-104.

Augusto, L., Bakker, M. R., Lavaissière, C. De, Jordan-Meille, L. \& Saur, E. (2009). Estimation of Nutrient Content of Woody Plants Using Allometric Relationships: Quantifying the Difference between Concentration Values from the Literature and Actuals. Forestry, 82 (4), 463-77.

BAlboa, X. \& Fernández Prieto, L. (1996). Evolución de las formas de fertilización en la agricultura atlántica entre los siglos XIX-XX. In R. GARRABOU \& J. M. NAREDO (Eds.), La fertilización en los sistemas agrarios: Una perspectiva histórica (pp. 89-126). Madrid: Fundación Argentaria/Visor.

Caro Baroja, J. (1986). De la vida rural vasca. San Sebastián: Txertoa.

CARRIón, I. M. (1996). Los antiguos pesos y medidas guipuzcoanos. Vasconia, (24), 59-79.

CASCÓN, J. H. (1918). El estiércol y la alimentación animal. Madrid: Imprenta de Alrededor del Mundo.

Christiansen, S. (1996). Concentrational Agriculture:Types, Functions and Derivation. Geografisk Tidsskrift, (96), 123-28.

Christiansen, S. (2001). Flows of Matter in a Traditional Heathland Farm about 1840: An Example from Northern West Jutland, Denmark. Geografisk Tidsskrift, 101 (1), 4366.

Corbacho, B. (2017). Intensification of a Peasant Agriculture and Soil Fertility in an Atlantic Territory: Galicia, 1750-1900. PhD thesis. Santiago de Compostela: Universidade de Santiago de Compostela.

Davidson, D. A. (1982). Soils and Man in the Past. In E. M. Bridges \& D. A. DAvidson (Eds.), Principles and Applications of Soil Geography (pp. 1-27). London: Longman. DougLASs, W. A. (1971). Rural Exodus in Two Spanish Basque Villages: A Cultural Explanation. American Anthropologist, 73 (5), 1100-44.

Douglass, W. A. (1977). Echalar y Murélaga: Oportunidad y éxodo rural en dos aldeas vascas. 2 vols. Donostia: Auñamendi. 
Egunjobi, J. K. (1971). Ecosystem Processes in a Stand of Ulex europaeus L. I.: Dry Matter Production, Litter Fall and Efficiency of Solar Energy Utilization. Fournal of Ecology, 59 (1), 31-8.

EnRíQuez, J. C. (1996). Aulesti: Un modelo local de desarrollo histórico. Bilbao: Diputación Foral de Bizkaia.

Evans, R. (1990). Soil Erosion: Its Impact on the English and Welsh Landscape Since Woodland Clearance. In J. Boardman, I. D. L. Foster \& J. A. Dearing (Eds.), Soil Erosion on Agricultural Land (pp. 231-54). Chichester: John Wiley and Sons.

Fernández Albaladejo, P. (1975). La crisis del Antiguo Régimen en Guipúzcoa, 17661833: Cambio económico e historia. Madrid: Akal.

FERnÁNDEZ PINEDO, E. (1974). Crecimiento económico y transformaciones sociales del País Vasco, 1100/1850. Madrid: Siglo XXI.

FlORES DE LEMUS, A. (1976). Sobre una dirección fundamental de la producción rural española. Hacienda Pública Española, (42-43), 471-85.

Foster, J. B. (2000). Marx's Ecology: Materialism and Nature. New York: Monthly Review.

Galán del Castillo, E. (2017). Feeding Soils: Nutrient Balance in the Northeast of the Iberian Peninsula c. 1920. Historia Agraria, (72), 107-34.

Galarza, A. (2000). Ispaster y Amoroto. Bilbao: Beta.

GARAGARZA, E. (1859). Cultivo agrario deVizcaya y sus necesidades más urgentes. Bilbao: Imprenta y Litografía de D. Juan E. Delmas.

GARAGARZA, E. (1859-1861). Plan de cultivo y plan de enseñanza de la Escuela práctica de Agricultura de la M. N. y M. L. Provincia de Álava. In JunTa Directiva DE LA ExPOSICIÓN GENERAL DE 1857, Memoria sobre los productos de la agricultura española reunidos en la Exposición General de 1857 (pp. 203-7). Madrid: Imprenta Nacional.

Giampietro, M., Cerretelli, G. \& Pimentel, D. (1992). Assessment of Different Agricultural Production Practices. Ambio, 21 (7), 451-59.

GogeascoecheA, A. (1993). Los montes comunales en la merindad de Busturia, siglos XVIII-XIX. PhD thesis. Leioa: Euskal Herriko Unibertsitatea.

Gogeascoechea, A. (1994). El romanticismo: 1800-1876. In VV. AA., Pensamiento agrario vasco: Mitos y realidades (1766-1980) (pp. 79-97). Bilbao: Euskal Herriko Unibertsitatea.

Golding, K. A., Simpson, I. A., Wilson, C. A., Lowe, E. C., Schofield, J. E. \& EDWARDS, K. J. (2015). Europeanization of Sub-Arctic Environments: Perspectives from Norse Greenland's Outer Fjords. Human Ecology, 43 (1), 61-77.

GonZÁlez Cembelíín, J. M. (1990). La introducción y difusión del maíz en el concejo de Güeñes. Vasconia. Cuadernos de Historia-Geografía, (17), 87-111.

González de Molina, M., García Ruiz, R., Soto, D., Guzmán, G., Cid, A. \& Infante, J. (2015). Nutrient Balances and Management of Soil Fertility Prior to the Arrival of 
Chemical Fertilizers in Andalusia, Southern Spain. Human Ecology Review, 21 (2), 23-48.

GreEnwood, D. J. (1976). Unrewarding Wealth:The Commercialization and Collapse of Agriculture in a Spanish Basque Town. Cambridge: Cambridge University Press.

Hueting, R. \& ReIjNDERs, L. (1998). Sustainability is an Objective Concept. Ecological Economics, 27 (2), 139-47.

Humboldt, W. von (1999). Los vascos. Donostia: Roger Editor.

ITURRIZA, J. R. (1885). Historia general deVizcaya. Bilbao: Imprenta de Cipriano Lucena y Compañía. (Originally published in 1787).

KIrCH, P. V. (1994). The Wet and the Dry: Irrigation and Agricultural Intensification in Polynesia. Chicago: The University of Chicago Press.

Koerner, W., Dupouey, J. L., DAmbrine, E. \& Benoît, M. (1997). Influence of Past Land Use on the Vegetation and Soils of Present Day Forest in the Vosges Mountains, France. fournal of Ecology, 85 (3), 351-58.

Ladefoged, T. N. \& Graves, M. W. (2010). The Leeward Kohala Field system. In P.V. KIRCH (Ed.), Roots of Conflict: Soils, Agriculture, and Sociopolitical Complexity in Ancient Hawai'i (pp. 89-110). Santa Fe: School for Advanced Research Press.

LAFFITE, V. (1918). Agricultura y ganadería vascongadas. In F. CARRERAS (Dir.), Geografía general del País Vasco-Navarro (pp. 571-646). Barcelona: Editorial de Alberto Martín.

LAfFite, V. (1919). Explotación del suelo del caserío. In Primer Congreso de EstudiosVas$\cos$ (pp. 219-236). Bilbao: Bilbaína de Artes Gráficas.

LANGE, J. (1996). Economía rural tradicional en un valle vasco: Sobre el desarrollo de estructuras mercantiles en Zeberio en el siglo XVIII. Bilbao: Beitia.

LANGOHR, R. (2001). L'anthropisation du paysage pédologique agricole de la Belgique depuis le Néolithique ancien: Apports de l'archéopédologie. Étude et gestion des sols, 8 (2), 103-18.

LANZA, R. (1996). La ganadería vacuna del País Vasco (1850-1950): Principales caracteres y factores de su evolución. In R. Domínguez MARTín (Coord.), La vocación ganadera del Norte de España: Del modelo tradicional a los desafios del mercado mundial (pp. 147206). Madrid: Ministerio de Agricultura, Alimentación y Medio Ambiente.

LARRAMENDI, M. DE (1985). Corografía de la provincia de Guipúzcoa. Echevarri: Amigos del Libro Vasco. (Originally published in 1754).

Lasanta, T., NADAL-Romero, E. \& ERrEA, M. P. (2017). The Footprint of Marginal Agriculture in the Mediterranean Mountain Landscape: An Analysis of the Central Spanish Pyrenees. Science of the Total Environment, (599-600), 1823-36.

López Musatadi, M. J. (1998). Ispaster y Ea. Bilbao: Diputación Foral de Bizkaia.

Lorenzo, F. A. (1996). Markina-Xemein. Bilbao: Diputación Foral de Bizkaia.

Madoz, P. (1990). Diccionario geográfico-estadístico-histórico de España y sus posesiones de ultramar:Vizcaya-Bizkaia.Valladolid: Ambito. (Originally published in 1845-1850). 
Martínez Fernández, I. (1993). Amoroto, Gizaburuaga y Mendexa. Bilbao: Diputación Foral de Bizkaia.

Mathew, W. M. (1993). Marling in British Agriculture: A Case of Partial Identity. The Agricultural History Review, 41 (2), 97-110.

MiÑana, J. M. (1980). Estudio de productividades. In SociedAd DE Ciencias ARANZADI (Ed.), Estudio ecológico y económico de las repoblaciones de coníferas exóticas en el País Vasco (pp. 891-1008). Vol. 2. Mondragón: Caja Laboral Popular.

Newman, E. I. (1997). Phosphorus Balance of Contrasting Farming Systems, Past and Present: Can Food Production be Sustainable? fournal of Applied Ecology, 34 (6), 1334-47.

Newman, E. I. \& Harvey, P. D. A. (1997). Did Soil Fertility Decline in Medieval English Farms?: Evidence from Cuxham, Oxfordshire, 1320-1340. The Agricultural History Review, 45 (2), 119-36.

OlabarRia, F. J. (1997). Munitibar-Arbatzegi-Gerrikaitz y Mendata. Bilbao: Diputación Foral de Bizkaia.

OlARIETA, J. R. (1993). Estudio de delimitación de zonas agrarias de protección especial en la comarca de Lea-Artibai (Bizkaia). Markina: Markina-Ondarroa Mendi Nekazaritza Alkartea.

Olarieta, J. R., Besga, G., Rodríguez OchoA, R., Aizpurua, A. \& Usón, A. (2006). Land Evaluation for Forestry: A Study of the Land Requirements for Growing Pinus radiata D. Don in the Basque Country, Northern Spain. Soil Use and Management, 22 (3), 238-44.

Olarieta, J. R., Besga, G., Rodríguez Ochoa, R. \& Aizpurua, A. (2007). Efecto del decapado, en comparación a la quema de restos, sobre las características del suelo y el crecimiento de plántulas de Pinus radiata. Edafología, 14 (1-3), 9-18.

Olarieta, J. R., Padró, R., Massip, G., Rodríguez Ochoa, R. \& Tello, E. (2011). 'Formiguers', a Historical System of Soil Fertilization (and Biochar Production?). Agriculture, Ecosystems and Environment, 140 (1-2), 27-33.

OlazÁBAL, L. (1857). Suelo, clima, cultivo agrario y forestal de la provincia de Vizcaya. Madrid: Imprenta, Fundición y Librería de Don Eusebio Aguado.

Otaegui, A. (1984). Aprovechamientos comunales en los montes francos de Urnieta (Guipúzcoa) y su progresiva desintegración durante los años 1882-1958. Documents d'Anàlisi Geogràfica, (4), 103-16.

Prado, A. I. (2004). Lekeitio II. Bilbao: Diputación Foral de Bizkaia.

RichteR, D. D. \& MARkewitz, D. (2001). Understanding Soil Change. Cambridge: Cambridge University Press.

Rowell, D. L. (1988). Soil Acidity and Alkalinity. In A. WILD (Ed.), Russell's Soil Conditions and Plant Growth (pp. 844-98). New York: Longman. 
Sociedad Bascongada de los Amigos del País (SBAP) (1768). Ensayo de la Sociedad Bascongada de los Amigos del País. Vitoria:Thomás de Robles.

SCHNEIDER, M. \& MCMichael, P. (2010). Deepening, and Repairing, the Metabolic Rift. Fournal of Peasant Studies, 37 (3), 461-84.

Soto, B., Basanta, R., Pérez, R. \& Díaz-Fierros, F. (1995). An Experimental Study of the Influence of Traditional Slash-and-Burn Practices on Soil Erosion. Catena, 24 (1), 13-23.

Tello, E., Garrabou, R., Cussó, X. \& Olarieta, J. R. (2010). Sobre la sostenibilidad de los sistemas agrarios: Balances de nutrientes y sistemas de fertilización en la agricultura catalana a mediados del siglo XIX. In R. GARRABOU \& M. GonZÁleZ DE Molina (Eds.), La reposición de la fertilidad en los sistemas agrarios tradicionales (pp. 171-215). Barcelona: Icaria.

Tello, E., Garrabou, R., Cussó, X., Olarieta, J. R. \& Galán, E. (2012). Fertilizing Methods and Nutrient Balance at the End of Traditional Organic Agriculture in the Mediterranean Bioregion: Catalonia (Spain) in the 1860s. Human Ecology, 40 (3), 369-83.

Tello, E., Martínez, J. L., Jover-Avellà, G., Olarieta, J. R., García-Ruiz, R., González de Molina, M., Badía-Miró, M., Winiwarter, V. \& Koepke, N. (2017). The Onset of the English Agricultural Revolution: Climate Factors and Soil Nutrients. Fournal of Interdisciplinary History, 47 (4), 445-74.

Trueba, D. (1956). Estudio económico de la agricultura vizcaína. Revista de Estudios Agrosociales, (14), 7-44.

Unamuno, M. (1896). Derecho consuetudinario de España:Vizcaya. Revista General de Legislación y furisprudencia, 44 (88), 42-71.

URZAINQUi, A. (2007). De montes, parzonerías y parques naturales: Comunidades de montes en Gipuzkoa: Las parzonerías. San Sebastián: Universidad de Deusto.

VICARIo, N. (1901). Derecho consuetudinario deVizcaya. Madrid: Real Academia de Ciencias Morales y Políticas.

Vitousek, P. M., Chadwick, O. A., Hartshorn, A. S. \& Hotchisiss, S. C. (2010). Intensive Agriculture in Hawai'i: The Model System Approach. In P.V. KIRCH (Ed.), Roots of Conflict: Soils, Agriculture, and Sociopolitical Complexity in Ancient Hawai'i (pp. 31-44). Santa Fe: School for Advanced Research Press.

WaLsh, T., RYAN, P. F. \& KILROY, J. (1957). A Half Century of Fertilizer and Lime Use in Ireland. Fournal of the Statistical and Social Inquiry Society of Ireland, (19), 104-36. WaTt, A. S. (1956). Contributions to the Ecology of Bracken (Pteridium aquilinum). vII: Bracken and litter. I: Origin of the Rings. Nerw Phytologist, 55 (3), 369-81.

Zamacola, J. A. (1900). Historia de las naciones vascas. Vol. III. Bilbao: Imprenta y Librería de José de Astuy. 